\title{
SIGNIFICANT LEVELS OF STEEL SLAG CONCRETE PRODUCED WITH VARYING WATER CEMENT RATIOS
}

\author{
SOLOMON IDOWU ADEDOKUN ${ }^{1}$, MUKAILA ABIOLA ANIFOWOSE ${ }^{* 2}$, \\ SAMSON OLALEKAN ODEYEMI ${ }^{3}$, JOHNSON ROTIMI OLUREMI ${ }^{4}$ \\ ${ }^{1}$ Department of Civil and Environmental Engineering, University of Lagos, Yaba, 100213, \\ Nigeria \\ ${ }^{2}$ Department of Civil Engineering, The Federal Polytechnic Offa, Offa, 250101, Nigeria \\ ${ }^{3}$ Department of Civil Engineering, Kwara State University, Malete, 241104, Nigeria \\ ${ }^{4}$ Department of Civil Engineering, Ladoke Akintola University of Technology, Ogbomoso, \\ 210214, Nigeria
}

\begin{abstract}
This study investigated the significance of steel slag concrete created with varying water cement ratios. Steel slag from Prism Nigeria Limited was used to replace granite (at 0, 40, 50 and $60 \%$ ) in concrete. Properties of this modified concrete were examined and its results were exposed to measurable test utilizing Analysis of Variance (ANOVA). The outcome indicated that the compressive and flexural qualities of the concrete increased with increased in slag content but consistently decreased as the watercement ratios increased. The p-values of the ANOVA test for the models term are significant because they are less than 0.05 .
\end{abstract}

Keywords: concrete, compressive strength, flexural strength, steel slag, water-cement ratios

\section{INTRODUCTION}

Concrete is the most utilized development material which is shaped by cement, fine and coarse aggregate (crushed or uncrushed stone), admixtures (if required) and water [1-5]. Aggregates account for almost $75 \%$ of the concrete constituent. This lead to intrigue in the utilization of elective materials and exploration has been utilized on many exclusive substances as aggregate substitutes [6]. Adedokun et al. [7] and Raheem et al. [8-10] noted that the utilization of industrial and agricultural wastes are environmentally friendly method of disposing large of materials that would have constituted pollution to land, water and air. Steel slag are as of now being utilized in asphalt paving because of their firmness, mechanical energy, wear opposition, porosity and water retention potential. Moreover, metallic slag could be utilized as an incomplete substitute for coarse aggregates in concrete [11].

Steel slag is a by-product from metal assembling. It might be sorted as carbon steel slag and stainless steel slag according to the kind of steel, and as casting residue, Electric Arc Furnace Slag (EAFS), Basic Oxygen Furnace Slag (BOFS), Ladle Refining Slag (LFS) and pre-remedy slag in line with the steelmaking technique [12]. Steel slag have been found as a superior substitute for coarse aggregate in concrete production. Qurishee et al. [13] assessed the utilization of slag and its impact on concrete properties. It was noticed that compressive strength of slag concrete performs than ordinary concrete. The discoveries by Thangasel

\footnotetext{
* Corresponding author, email: mukaila.anifowose@fedpoffaonline.edu.ng

(C) 2021 Alma Mater Publishing House
} 
vi [14] proposed that compressive strength of concrete expanded up to $60 \%$ steel slag. Khafaga et al. [15] opined that the ideal steel slag aggregates as substitute of coarse aggregate to accomplish better split elasticity was gotten at $66.67 \%$ of steel slag. Nonetheless, Subramani and Ravi [16] analyzed the substitute of granite utilizing steel slag in concrete. The result affirmed that concrete with $60 \%$ steel slag has better flexural strength at 28 days of relieving age. Past examinations on substitution of granite with steel slag significantly cantered around the assurance of compressive, split tensile and flexural strength but did not comprehensively examine the effect of water-cement proportions (W-C) on the properties of steel slag concrete.

This examination subsequently surveyed the effect of W-C on the properties of concrete created with substitution of coarse aggregate with Electric Arc Furnace Slag (EAFS) produced by Prism Nigeria Limited, Ikirun, Osun State, Nigeria. It includes the determination of the actual properties of the steel slag and granite; the examination of the effect of water-cement ratios on the slump and compacting factor, compressive and flexural qualities (strength) of steel slag concrete.

\section{MATERIALS AND METHODS}

\subsection{Materials}

Cement brand of 32.5R that conformed to NIS 444-1 [17] with water that conformed to NIS 554 [18] were used for concrete production. Fine aggregate that goes through strainer $5.0 \mathrm{~mm}$ and granite of extreme size $12.5 \mathrm{~mm}$ which conforms to BS 882 [19] were utilized. Steel slags were collected from Prism Nig. Ltd., along OsogboIkirun Road, Ikirun, Osun State, Nigeria and were identified as Prism Nigeria Slag (PNS). The steel slags were broken down manually with hammer into required sizes and allow to pass through British Standard sieve 13.2 $\mathrm{mm}$ and retained on sieve $5.0 \mathrm{~mm}$. The PNS was subjected to oxide composition test (Table 1) at NASENI Centre of Excellence, Nanotechnology and Advanced Material, Akure, Nigeria using X-Ray Fluorescence (XRF) techniques.

Table 1. Oxide composition of PNS.

\begin{tabular}{|c|c|}
\hline Oxides & Composition (\%) \\
\hline $\mathrm{SiO}_{2}$ & 35.68 \\
\hline $\mathrm{Al}_{2} \mathrm{O}_{3}$ & 11.28 \\
\hline $\mathrm{Fe}_{2} \mathrm{O}_{3}$ & 46.93 \\
\hline $\mathrm{CaO}$ & 11.07 \\
\hline $\mathrm{MgO}$ & - \\
\hline $\mathrm{K}_{2} \mathrm{O}$ & 0.87 \\
\hline $\mathrm{MnO}$ & 6.89 \\
\hline $\mathrm{TiO}_{2}$ & 0.94 \\
\hline $\mathrm{P}_{2} \mathrm{O}_{5}$ & 0.33 \\
\hline
\end{tabular}

\subsection{Methods}

This examination analysed the ideal supplement of granite with steel slag in concrete. The specific gravity, aggregate crushing value and aggregate impact value of the steel slag and crushed stone were determined in accordance British Standards. The study considered the effect varying water-cement ratios on the optimum replacements of crushed stone (granite) with steel slag ( 0 as control, 40, 50 and $60 \%$ ) reported by Khafaga et al. [15], Subramani and Ravi [16] and Thangaselvi [14]. A concrete mix proportion of 1:2:4 was adopted and batched by weight with W-C of $0.4,0.5,0.6$ and 0.7 utilizing cement weight of $300 \mathrm{~kg} / \mathrm{m}^{3}$. Total number of thirty-two (32) squares of sizes $150 \times 150 \times 150 \mathrm{~mm}$ (24 for PNS and 8 for conventional concrete) and 32 prism concrete samples of sizes $100 \times 100 \times 500 \mathrm{~mm}$ (24 prism for PNS and 8 prisms for conventional concrete) were produced. The concrete specimens were cured by submersion in water for 28 days. Toward the finish of each curing ages, the compressive and flexural qualities were determined on the concrete cubes and prism concrete samples, respectively. Haida Universal Testing Machine (UTM) of $2000 \mathrm{kN}$ capacity at Materials and Structures Laboratory, Civil Engineering Department, Osun State University, Osogbo, Nigeria was used to determine compressive and flexural qualities of the concrete. The qualities of the concrete were additionally exposed to Analysis of Variance (ANOVA) using Design Expert Version 7.0 Software to determine the significance levels of the model terms. 


\section{RESULTS AND DISCUSSION}

\subsection{Physical properties}

Table 2 presents the physical properties of the aggregates used in this study. These results showed that PNS has higher specific gravity than sand and granite. In addition, the aggregate impact value (AIV) of the PNS were lower than that of granite, which is indicates that PNS has better degree of resistance to an unexpected impact than granite. Finally, the relatively lower aggregate crushing value (ACV) of PNS shows that it can withstand a gradually applied compression load than granite used.

Table 2. Physical properties of aggregate.

\begin{tabular}{|c|c|c|c|c|}
\hline \multirow{2}{*}{ Test Results } & \multicolumn{3}{|c|}{ Aggregate } & \multirow{2}{*}{ Test conformity } \\
\cline { 2 - 4 } & $\begin{array}{c}\text { Fine } \\
\text { aggregate }\end{array}$ & $\begin{array}{c}\text { Coarse } \\
\text { aggregate }\end{array}$ & PNS & \\
\hline Specific Gravity & 2.67 & 2.69 & 2.71 & BS 1377:2 [20] \\
\hline AIV & & $12.5 \%$ & $7.14 \%$ & BS 812-112 [21] \\
\hline ACV & & $24.6 \%$ & $19.67 \%$ & BS 812-110 [22] \\
\hline
\end{tabular}

\subsection{Slump}

The slump result for PNS-Fresh-Concrete are presented in Figure 1. The results indicated that, as the water contents in the fresh concrete mix expanded, the PNS-Fresh-Concrete-Mix turned out to be more functional. However, the slump value of the concrete decreased with the increasing content of the steel slag. This indicated that the concrete became less workable as the slag content increased.

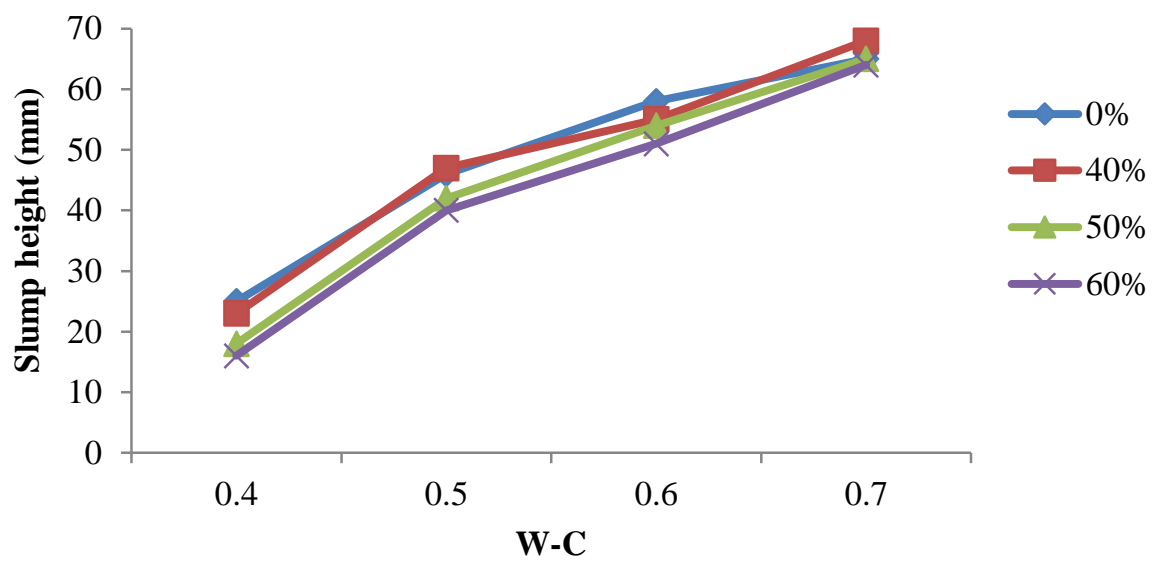

Fig. 1. PNS-slump height against W-C.

\subsection{Compacting factor}

Figure 2 shows the effect of W-C and steel slag on the compacting factor of PNS-Concrete. The trend of the values corresponds to those of slump results. The higher the $\mathrm{W}-\mathrm{C}$, the higher the compacting factor value. However, the higher the steel slag content, the lower the compacting factor value. Li [23] opined that the range of compaction factor of fresh concrete is within 0.78 and 0.95 . However, BS 1881:103 [24] specified the range of compacting factor as 0.70 to 0.98 . The results obtained (in Figure 2) ranged between 0.92 and 0.95 , which also fell within both specified ranges.

The slump and compacting factor values showed that increased in steel slag contents decreased the workability of the concrete, while increase in volume of W-C leads to an increase in the workability. 


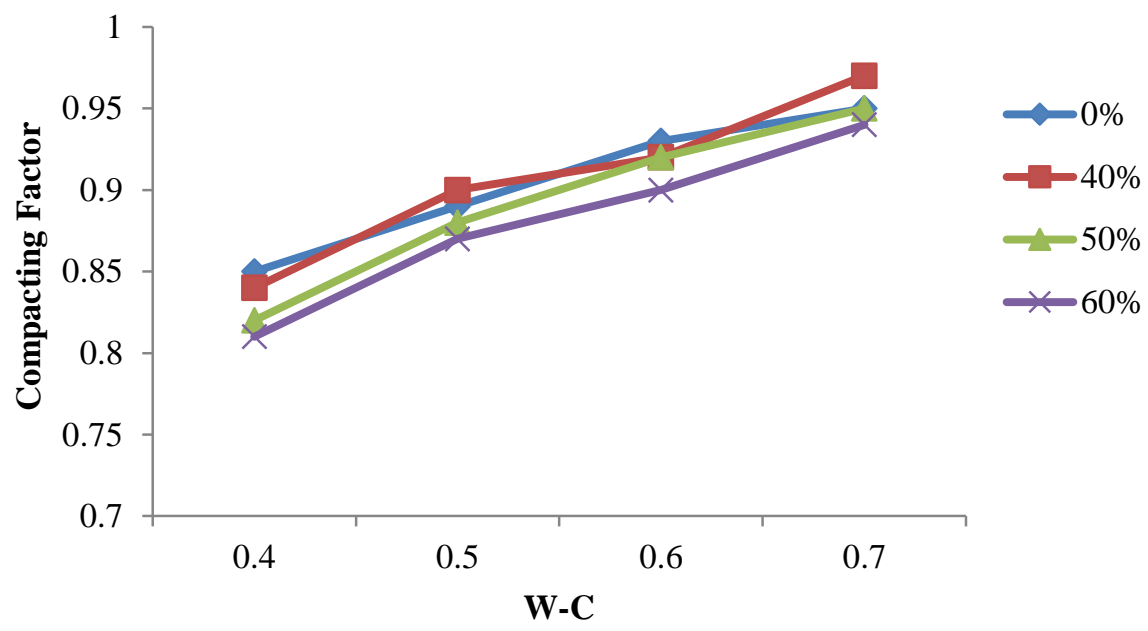

Fig. 2. PNS-compacting factor against W-C.

\subsection{Compressive strength}

The consequences of the PNS-Hardened-Concrete under changing W-C and steel slag were introduced in Figure 3. The PNS-Compressive strength results show that the qualities diminished as the W-C expanded. The compressive strength expanded up to 40\% PNS and diminished at $50 \%$ PNS substitutes of granite but further increased at $60 \%$ PNS replacements in W-C of $0.4,0.5,0.6$ and 0.7 . W-C of 0.4 has the highest compressive strength while W-C of 0.7 has the least strength. This result is in agreement with the previous study reported by Thangaselvi [14], which noted an ideal steel slag substitute of $60 \%$ by weight of the granite in concrete.



Fig. 3. Response surface plot of PNS compressive strength.

The ANOVA of PNS compressive strength for response surface cubic model is presented in Table 3 while Table 4 shows the ANOVA summary statistics. The Model F-Value of 310.27 infers that the model is significant. Values of "Prob $>F$ " lower than 0.0500 shows that model terms are significant. The "Pred R-Squared" of 0.9651 correlate with the "Adj-R-Square" of 0.9946. That is, the difference is less than 0.2. "Adeq Precision" ratio higher than 4 is acceptable. Ratio of 49.968 (Table 4) indicates an adequate signal. 
Table 3. ANOVA of PNS compressive strength.

\begin{tabular}{|c|c|c|c|c|c|}
\hline Source & $\begin{array}{c}\text { Sum of } \\
\text { squares }\end{array}$ & df & $\begin{array}{c}\text { Mean } \\
\text { square }\end{array}$ & F value & $\begin{array}{c}\text { p-value } \\
\text { Prob>F }\end{array}$ \\
\hline Model & 106.96 & 9 & 11.88 & 310.27 & $<0.0001$ \\
\hline $\mathrm{A}-\mathrm{W} / \mathrm{C}$ & 4.27 & 1 & 4.27 & 111.53 & $<0.0001$ \\
\hline $\mathrm{B}-\mathrm{PNS} \mathrm{Slag}$ & 0.90 & 1 & 0.90 & 23.60 & 0.0028 \\
\hline $\mathrm{AB}$ & 0.044 & 1 & 0.044 & 1.14 & 0.3263 \\
\hline $\mathrm{A}^{2}$ & 12.10 & 1 & 12.10 & 315.93 & $<0.0001$ \\
\hline $\mathrm{B}^{2}$ & 0.55 & 1 & 0.55 & 14.26 & 0.0092 \\
\hline $\mathrm{A}^{2} \mathrm{~B}$ & 0.13 & 1 & 0.13 & 3.46 & 0.1121 \\
\hline $\mathrm{AB}^{2}$ & 0.084 & 1 & 0.084 & 2.19 & 0.1894 \\
\hline $\mathrm{A}^{3}$ & 0.28 & 1 & 0.28 & 7.30 & 0.0355 \\
\hline $\mathrm{B}^{3}$ & 1.12 & 1 & 1.12 & 29.25 & 0.0017 \\
\hline Residual & 0.23 & 6 & 0.038 & & \\
\hline Cor Total & 107.19 & 15 & & & \\
\hline
\end{tabular}

Table 4. ANOVA summary statistics of PNS compressive strength.

\begin{tabular}{|l|l|l|l|}
\hline Std. Dev. & 0.20 & R-Square & 0.9979 \\
\hline Mean & 24.30 & Adj R-square & 0.9946 \\
\hline C.V.\% & 0.81 & Pred R-Square & 0.9651 \\
\hline PRESS & 3.74 & Adeq Precision & 49.968 \\
\hline
\end{tabular}

\subsection{Flexural strength}

The conduct of flexural strength of concrete under varying W-C and steel slag contents were presented in Figure 4. These results showed a reduction in PNS-Flexural strength as the $\mathrm{W}-\mathrm{C}$ increased from 0.4 to 0.7 . The most elevated flexural strength was noticed for W-C of 0.4 while that of 0.7 has the least flexural strength (this was like that of compressive strength). For varying steel slag contents, the flexural strength increased from 0 to $40 \%$ PNS replacement but it was reduced at 50 and $60 \%$ PNS substitution for all W-C. This ideal percentage replacement of $40 \%$ was however lower than $60 \%$ reported by Subramani and Ravi [16]. This might be as a result difference in the chemical composition and actual properties of the steel slag acquired from contrast organizations.

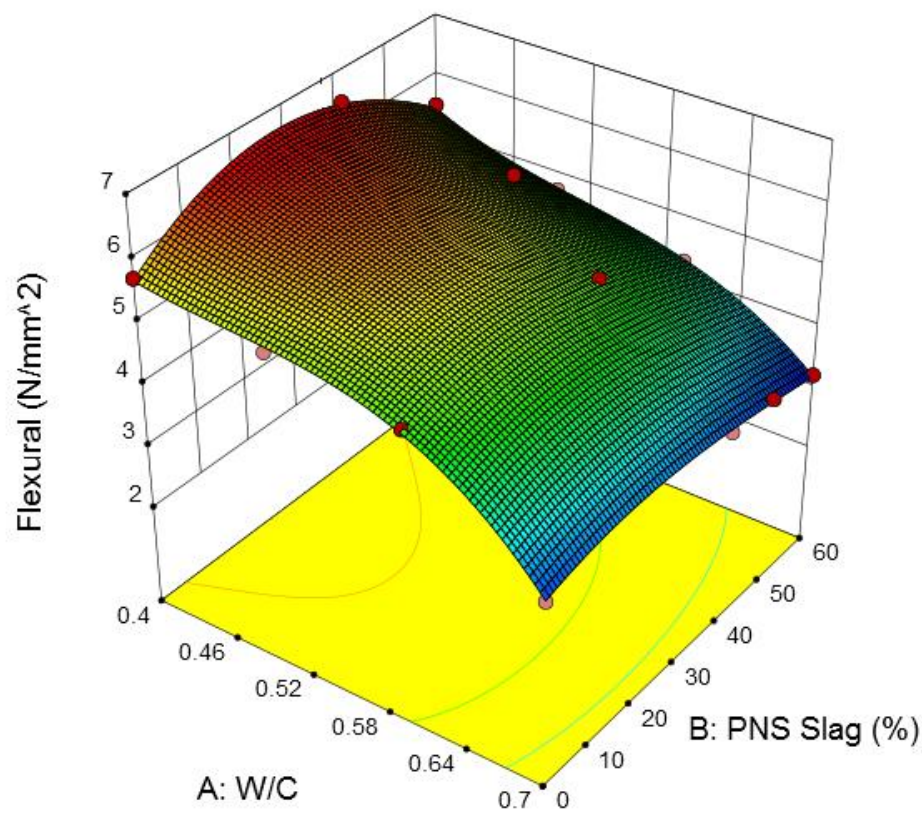

Fig. 4. Response surface plot of PNS flexural strength.

The ANOVA of PNS flexural strength for response surface cubic model is presented in Table 5 while Table 6 shows the ANOVA summary statistics. The Model F-Value of 122.65 infers the model is significant. Values of 
"Prob $>F$ " lower than 0.0500 shows that model terms are significant. The "Pred R-Squared" of 0.9449 correlate with the "Adj-R-Square" of 0.9946. That is, the difference is less than 0.2. Ratio of 34.596 (Table 6) shows a satisfactory sign since the "Adeq Precision" proportion is higher than 4.

Table 5. ANOVA of PNS flexural strength.

\begin{tabular}{|c|c|c|c|c|c|}
\hline Source & Sum of squares & df & Mean square & F value & $\begin{array}{c}\text { p-value } \\
\text { Prob }>\mathbf{F}\end{array}$ \\
\hline Model & 15.60 & 9 & 1.73 & 122.65 & $<0.0001$ \\
\hline $\mathrm{A}-\mathrm{W} / \mathrm{C}$ & 0.56 & 1 & 0.56 & 39.70 & $<0.0007$ \\
\hline $\mathrm{B}-\mathrm{PNS} \mathrm{Slag}$ & 0.020 & 1 & 0.020 & 1.40 & 0.2811 \\
\hline $\mathrm{AB}$ & $1.406 \mathrm{E}-004$ & 1 & $1.406 \mathrm{E}-004$ & $9.951 \mathrm{E}-003$ & 0.9238 \\
\hline $\mathrm{A}^{2}$ & 0.85 & 1 & 0.85 & 60.49 & 0.0002 \\
\hline $\mathrm{B}^{2}$ & 0.23 & 1 & 0.23 & 15.98 & 0.0071 \\
\hline $\mathrm{A}^{2} \mathrm{~B}$ & 0.11 & 1 & 0.11 & 8.02 & 0.0299 \\
\hline $\mathrm{AB}^{2}$ & 0.17 & 1 & 0.17 & 11.78 & 0.0139 \\
\hline $\mathrm{A}^{3}$ & 0.16 & 1 & 0.16 & 11.15 & 0.0156 \\
\hline $\mathrm{B}^{3}$ & $1.065 \mathrm{E}-003$ & 1 & $1.065 \mathrm{E}-003$ & 0.075 & 0.7929 \\
\hline Residual & 0.085 & 6 & 0.014 & & \\
\hline Cor Total & 15.68 & 15 & & & \\
\hline
\end{tabular}

Table 6. ANOVA summary statistics of PNS flexural strength.

\begin{tabular}{|l|l|l|l|}
\hline Std. Dev. & 0.12 & R-Square & 0.9946 \\
\hline Mean & 4.86 & Adj R-square & 0.9865 \\
\hline C.V.\% & 2.45 & Pred R-Square & 0.9449 \\
\hline PRESS & 0.86 & Adeq Precision & 34.596 \\
\hline
\end{tabular}

\section{CONCLUSIONS}

The significance levels of the concrete produced with varying W-C and replacements of granite with steel slag (produced by Prism Nigeria Limited) has been investigated and the following conclusions were made:

- The slump and compacting factor values showed increased in steel slag contents decreased the workability of concrete, while expansion in volume of W-C improved the functionality;

- The compressive strength of the concrete extended up to $60 \%$ substitute of granite with steel slag, due higher specific gravity of the slag contrast to that of granite. However, these strength decreased with W-C. W-C of 0.4 indicated the most elevated compressive strength while that of 0.7 has the least.

- The flexural strength of the concrete expanded from 0 to $40 \%$ of steel slag replacement but it was reduced with further increase of steel slag. Meanwhile, beam flexural strength became lesser as the W-C increased.

- The p-values of the Analysis of Variance (ANOVA) test of compressive and flexural strengths shows that the models term are significant because they are less than 0.05 .

- $60 \%$ PNS would produce a concrete of high compressive strength while $40 \%$ PNS would produce better flexural strength for $\mathrm{W}-\mathrm{C}$ of $0.4,0.5,0.6$ and 0.7 . Concrete with $\mathrm{W}-\mathrm{C}$ of 0.4 has the highest strength while $\mathrm{W}-\mathrm{C}$ of 0.7 has the least strength. This infers that increased in water-cement ratio gave decreased in strength of concrete.

\section{REFERENCES}

[1] Abdul, K.J., Dhanalakshmi, G., Experimental investigation on concrete by partial replacement on cement by bentonite and coarse aggregate by steel slag, International Journal of Innovative Research in Science, Engineering and Technology, vol. 5, no. 6, 2016, p. 10302-10309.

[2] Anifowose, M.A., Adebara, S.A., Odeyemi, S.O., Olahan, A.B., Aliyu, T., Density, workability and compressive strength assessment of steel slag in concrete, Acta Technica Corviniensis-Bulletin of Engineering Journal, vol. 10, no. 4, 2017, p. 63-67.

[3] Ige, J.A., Anifowose, M.A., Odeyemi, S.O., Adebara, S.A., Oyeleke, M.O., Assessment of rice husk ash (rha) and calcium chloride $\left(\mathrm{CaCl}_{2}\right)$ on compressive strength of concrete grade 20, International Journal of Engineering Research in Africa, vol. 40, 2018, p. 22-29. 
[4] Odeyemi, S.O., Anifowose, M.A., Oyeleke, M.O., Adeyemi, A.O., Bakare, S.B., Effect of calcium chloride on the compressive strength of concrete produced from three brands of Nigerian cement, American Journal of Civil Engineering, vol. 3, no. 2-3, 2015, p. 1-5.

[5] Anifowose, M.A., Adeyemi, A.O., Odeyemi, S.O., Abdulwahab, R., Mudashiru, R.B., Comparative study of Ikirun and Osogbo slag on concrete grade 20, Nigerian Journal of Technology, vol. 38, no. 2, 2019, p. 283-288.

[6] Ravikumar, H., Dattatreya, J.K., Shivananda, K.P., Experimental investigation on replacement of steel slag as coarse aggregate in concrete, Journal of Civil Engineering and Environmental Technology, vol. 2, no. 11, 2015, p. 58-63.

[7] Adedokun, S.I., Ajamu, S.O., Aderinto, H.T., Effect of synthetic hair fibre additions on the strength characteristics of concrete, Journal of Research in Civil Engineering, vol. 13, no. 2, 2016, p. 928-939.

[8] Raheem, A.A., Adedokun, S.I., Ajayi, B.R., Adedoyin, O.A., Adegboyega, B.O., Application of saw dust ash as partial replacement for cement in the production of interlocking paving stones, International Journal of Sustainable Construction Engineering and Technology, vol. 8, no. 1, 2017, p. 1-11.

[9] Raheem, A.A., Adedokun, S.I., Adeyinka, E.A., Adewole, B.V., Application of corn stalk ash as partial replacement for cement in the production of interlocking paving stones, International Journal of Engineering Research in Africa, vol. 30, 2017, p. 85-93.

[10] Raheem, A.A., Adedokun, S.I., Uthman, Q.A., Adeyemi, A.O., Oyeniyi, O.M., Application of corn husk ash as partial replacement for cement in the production of interlocking paving stones, Journal of Civil and Environmental Studies, vol. 1, no. 1, 2018, p. 14-20.

[11] Padmapriya, R., Bupesh, R.V.K., Kumar, V.G., Baalamurugan, J., Study on replacement of coarse aggregate by steel slag and fine aggregate by manufacturing sand in concrete, International Journal of Chemistry Chemical Research, vol. 8, no. 4, 2015, p. 1721-1729.

[12] Adedokun, S.I., Anifowose, M.A., Odeyemi, S.O., Assessment of steel slag as replacement for coarse aggregate in concrete: a review, Acta Technica Corviniensis-Bulletin of Engineering Journal, vol. 11, no. 4, 2018, p. 139-146.

[13] Qurishee, M.A., Iqbal, I.T., Islam, M.S., Islam, M.M., Use of slag as coarse aggregate and its effect on mechanical properties of concrete, Proceedings of the 3rd International Conference on Advances in Civil Engineering, CUET, 2016, p. 475-479.

[14] Thangaselvi, K., Strength and durability of concrete using steel slag as a partial replacement of coarse aggregate in concrete, International Journal of Advanced Research Trends in Engineering and Technology, vol. 2, no. 7, 2015, p. 1-6.

[15] Khafaga, M.A., Fahmy, W.S., Sherif, M.A., AbdelHamid, A.N., Properties of high strength concrete containing electric arc furnace steel slag aggregate, Journal of Engineering Sciences, vol. 42, no. 3, 2014, p. 582608.

[16] Subramani, T., Ravi, G., Experimental investigation of coarse aggregate with steel slag in concrete, Journal of Engineering, vol. 5, no. 5, 2015, 64-73.

[17] NIS 444-1, Nigerian Standard for Composition, Specifications and Conformity Criteria for Common Cements, Nigerian Industrial Standard, Lagos, 2014.

[18] NIS 554, Nigerian Standard for Drinking Water Quality, Nigerian Industrial Standard, Lagos, 2007.

[19] BS 882, British Standards Specification for Aggregates from Natural Sources for Concrete, British Standards Institutions, London, 1992.

[20] BS 1377-2, British Standards Methods of Test for Soil for Civil Engineering Purposes, British Standards Institutions, London, 1990.

[21] BS 812-112, British Standards for Testing Aggregate-Methods for Determination of Aggregate Impact Value (AIV), British Standards Institutions, London, 1990.

[22] BS 812-110, British Standards for Testing Aggregate-Methods for Determination of Aggregate Crushing Value (ACV), British Standards Institutions, London, 1990.

[23] Li, Z., Advanced concrete technology, Ed. John Wiley and Sons, Inc., New Jersey, 2011, p. 97-98

[24] BS 1881-103, British Standards for Testing Concrete-Method for Determination of Compacting Factor, British Standards Institutions, London, 1983. 